\author{
W. N. Tzeng · C. H. Wang $\cdot$ H. Wickström \\ M. Reizenstein
}

\title{
Occurrence of the semi-catadromous European eel Anguilla anguilla in the Baltic Sea
}

Received: 30 September 1999 / Accepted: 6 April 2000

\begin{abstract}
Strontium ( $\mathrm{Sr}$ ) and calcium $(\mathrm{Ca})$ contents in the otoliths of yellow and silver European eels [Anguilla anguilla (L.)] collected from coastal waters of the Baltic Sea and a freshwater lake in Sweden were examined by wavelength dispersive X-ray spectrometry with an electron microprobe. The mean $\mathrm{Sr} / \mathrm{Ca}$ ratios from elver check to otolith edge were significantly higher for the eels from coastal waters $(5.39 \pm 1.09 \%)$ than for those from the lake $(0.71 \pm 0.89 \%)$. The evidence indicates that European eels in the Baltic Sea do not necessarily migrate into freshwater streams during the growth phase.
\end{abstract}

\section{Introduction}

The European eel Anguilla anguilla has generally been considered a catadromous fish, spawning in the Sargasso Sea and growing in freshwater streams and lakes. The leaf-like larvae (leptocephali) migrate along with the North Equatorial Current, the Gulf Stream and the North Atlantic Current to European countries, metamorphose into glass eels on the continental shelf, and

Communicated by T. Ikeda, Hakodate

W. N. Tzeng $(\bowtie) \cdot C$. H. Wang

Department of Zoology, College of Science,

National Taiwan University, Taipei,

Taiwan 10617, R.O.C.

Tel.: + 886-2-23639570; Fax: + 886-2-23636837

e-mail:wnt@ccms.ntu.edu.tw

H. Wickström · M. Reizenstein

National Board of Fisheries, Institute of Freshwater Research,

17893 Drottningholm, Sweden

Present address:

C. H. Wang

Port Erin Marine Laboratory,

University of Liverpool, Isle of Man, UK then become elvers in estuaries (Bertin 1956). In general, the elvers migrate upstream to grow in freshwater into the yellow eel stage. At maturation, the yellow eels metamorphose into silver eels, which migrate downstream to the ocean for spawning (Tesch 1977).

During field observations, however, many yellow eels have been found in the marine habitat. It has been assumed that these eels were washed from rivers by floods or that elvers had not migrated to the freshwater habitat but had remained in coastal waters until maturation (Cairns 1942; D'Ancona 1960; Sinha and Jone 1966; Rossi 1979; Lee 1982). Such assumptions, however, have not yet been validated with any certainty.

Recent studies on otolith microchemistry have indicated that the past environmental history of fish can be reconstructed by analysis of the strontium $(\mathrm{Sr}) /$ calcium (Ca) ratio of the otolith (Radtke and Shafer 1992). The $\mathrm{Sr} / \mathrm{Ca}$ ratio has been found to differ between the freshwater and seawater phases in the life history of eels (Casselman 1982; Otake et al. 1994; Tzeng and Tsai 1994; Tzeng 1996; Tzeng et al. 1997). Thus, the $\mathrm{Sr} / \mathrm{Ca}$ ratios of otoliths may help in determining whether yellow eels actually stay in the marine habitat and do not migrate to freshwater at the elver stage to grow and metamorphose there until the silver eel stage.

European eels at the yellow-eel stage are widely distributed in freshwater, brackish water and seawater (Tesch 1977). Tsukamoto et al. (1998) examined the otolith $\mathrm{Sr} / \mathrm{Ca}$ ratio of European eels collected from offshore waters of the North Sea. They found that these eels did not migrate to freshwater but stayed in seawater until maturation. However, the question still remains whether eels from estuaries behave in the same manner. The Baltic Sea is a large estuary with an abundance of European eels. To validate whether the eels can remain in the Baltic Sea until maturation, we collected yellow and silver eels from coastal waters and from a freshwater lake in Sweden and examined the $\mathrm{Sr} / \mathrm{Ca}$ ratios in their otoliths. 


\section{Materials and methods}

\section{Anguilla anguilla collection}

Yellow (Groups Y1-8) and silver European eels (Groups S1-4) were collected from the coastal waters of Sweden and compared with a silver eel of known life history (Group S5) collected from a freshwater lake (Fig. 1). The yellow eels of Groups Y1-5 were caught while they migrated with tidal currents in brackish waters, Groups Y6 and Y8 were caught in their upstream migration into freshwater, and Group Y7 was caught by a trap constructed for catching downstream migratory eels. The silver eels of Groups S14 were also collected from brackish waters during their downstream migration, and Group S5 was from the freshwater Lake Fardume Trask in Gotland (Fig. 1). Groups S1-4 were of natural origin, whereas Group S5 consisted of stocked elvers imported from France in January and February 1980 (Holmgren 1996).

The salinity of Swedish coastal waters was measured at $25.54 \pm 3.38 \%$ in the west, $7.52 \pm 0.34 \%$ in the south and down to $5.66 \pm 0.25 \%$ in the east. The coastal waters of the Baltic Sea are brackish and are estuarine in character. The water temperature fluctuated greatly within a range of $-0.7^{\circ} \mathrm{C}$ in the winter to $21.1^{\circ} \mathrm{C}$ in the summer.

\section{Microchemical analysis}

A total of 18 yellow eels and 10 silver eels were used for the otolith microchemical analysis (Table 1). Sagittal otoliths were removed from the eels, air dried, embedded in thermo-epoxy (Petropoxy 154, Palouse Petro Products, USA), and cured for $1 \mathrm{~h}$ at $135^{\circ} \mathrm{C}$. Embedded otoliths were ground from the proximal side of the sagittal plane until the primordium was revealed. For microprobe analysis, the polished otoliths were coated under vacuum with a $30 \mathrm{~nm}$ layer of carbon to reduce X-ray diffraction and to increase electron conductance. The embedding, grinding and coating procedures

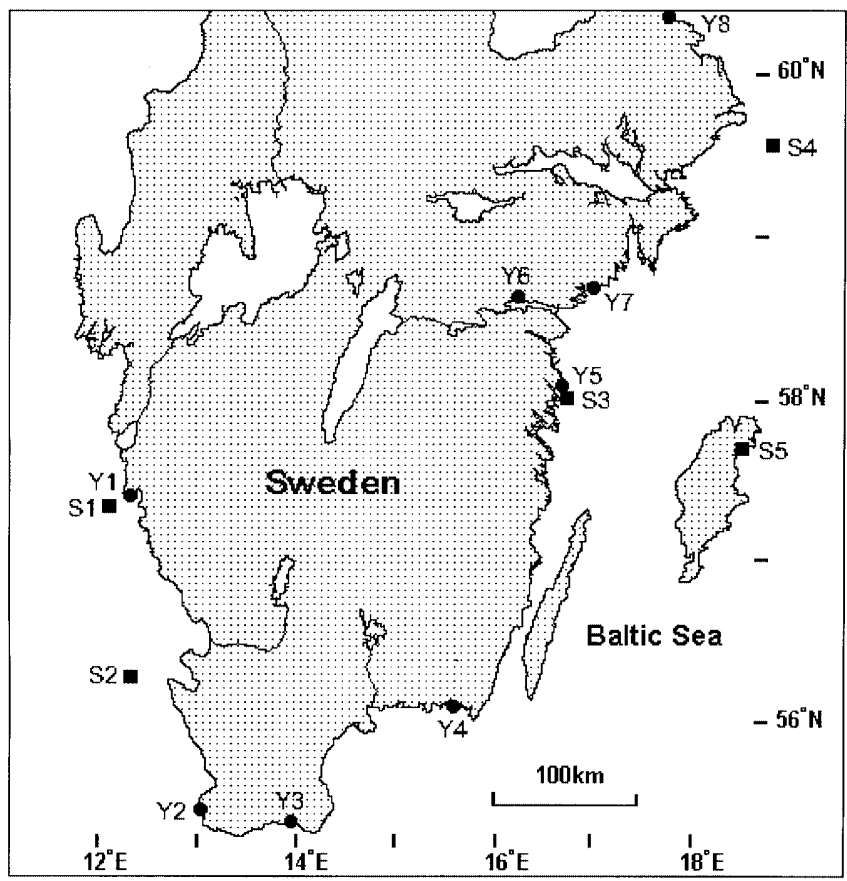

Fig. 1 Anguilla anguilla. Sampling locations of silver eels (S1-5) and yellow eels (Y1-8) from coastal waters (S1-4; Y1-8) and a freshwater lake (S5) in Sweden were similar to those described in a previous study (Tzeng and Tsai 1994).

Quantitative measurements of the concentrations of $\mathrm{Sr}$ and $\mathrm{Ca}$ in the otoliths were conducted, using an electron microprobe equipped with a wavelength-dispersive spectrometer (ShimadzuARL-EMX-SM7). The measurement procedures are similar to those described in a previous study (Tzeng and Tsai 1994). The electron beam was focused on an area approximately $5 \mu \mathrm{m}$ in diameter, at intervals of approximately $20 \mu \mathrm{m}$ from the primordium to the edge of the otolith. Subsequently, the $\mathrm{Sr} / \mathrm{Ca}$ ratio was calculated for each measuring spot. The $\mathrm{Sr} / \mathrm{Ca}$ ratios of Group S5 were used as a standard to evaluate the environmental history of the other eels (Table 1). Mean $\mathrm{Sr} / \mathrm{Ca}$ ratios from the elver stage to the eels at the time of collection were calculated. After microprobe analysis, the otoliths were repolished and etched with 5\% EDTA (ethylene diamine tetra-acetate; $\mathrm{pH}$ adjusted with $\mathrm{NaOH}$ to 7.4 ) to enhance metamorphosis- and elver-checks and annuli for age determination (Tzeng 1990; Tzeng and Tsai 1992; Tzeng et al. 1994).

\section{Results}

Temporal changes in $\mathrm{Sr} / \mathrm{Ca}$ ratios of yellow eels

The time series profiles of $\mathrm{Sr} / \mathrm{Ca}$ ratios of the otoliths of 18 yellow eels from eight groups are shown in Fig. 2. Changes in the $\mathrm{Sr} / \mathrm{Ca}$ ratios in relation to the migratory environmental history are explained as follows.

Groups Y1-5 were collected in coastal waters. Their ages ranged from $0+$ years in Group Y3 to $13+$ years in Group Y1 (Table 1). The $\mathrm{Sr} / \mathrm{Ca}$ ratios increased from 5 to $8 \%$ in the primordium to a peak of 18 to $20 \%$ at a position approximately $50 \mu \mathrm{m}$ from the primordium along the short axis of the otolith and $100 \mu \mathrm{m}$ from the primordium along the long axis. The peak corresponded to the time when leptocephali metamorphosed into glass eels. However, this peak was absent in Y8 (Fig. 2) and S1-3 eels (Fig. 3). The missing peak may be due to the $20 \mu \mathrm{m}$ interval, which could have been too large in the measurement of $\mathrm{Sr} / \mathrm{Ca}$ ratios to precisely locate the peak. The ratios after the elver stage (approximately $156 \mu \mathrm{m}$ from the primordium) varied between 3.5 and $7.5 \%$, with a mean of $5.39 \pm 1.09 \%$ (Fig. 2a to e), which was significantly higher than that of the freshwater eels, with a mean of $0.706 \pm 0.889$ (Fig. 3e) $(p<0.001)$. This indicates that the yellow eels in Groups Y1-5 stayed in brackish water from the elver stage until they were collected.

Groups Y6 and Y8 were collected during their upstream migration into freshwater. Their ages were $4+$ to $7+$ years. The $\mathrm{Sr} / \mathrm{Ca}$ ratio profiles of the three eels in Group Y6 and Eel No. AB3576 in Group Y8 dramatically decreased from approximately 5.0 to $<2 \%$ at a distance of 600 to $800 \mu \mathrm{m}$ from the primordium (Fig. 2f, h). However, the low level of the $\mathrm{Sr} / \mathrm{Ca}$ ratio was not close to zero. This indicates that these yellow eels were about midway in their migration from brackish water to freshwater.

The single eel of Group Y7 was caught by a trap for catching downstream migratory eels. It was $9+$ years old. The variable pattern of its $\mathrm{Sr} / \mathrm{Ca}$ ratios was similar 
Table 1 Anguilla anguilla. Biological and sampling information on the yellow and silver European eels collected in Sweden from brackish coastal waters and a freshwater lake ( $M$ male; $F$ female; nd (not determined))

\begin{tabular}{|c|c|c|c|c|c|c|c|}
\hline Group & $\begin{array}{l}\text { Specimen } \\
\text { No. }\end{array}$ & $\begin{array}{l}\text { Sampling } \\
\text { date }\end{array}$ & Sampling site & Sex & $\begin{array}{l}\text { Length } \\
(\mathrm{mm})\end{array}$ & $\begin{array}{l}\text { Weight } \\
\text { (g) }\end{array}$ & $\begin{array}{l}\text { Age } \\
(\mathrm{yr})\end{array}$ \\
\hline \multicolumn{8}{|c|}{ Yellow eels } \\
\hline \multirow[t]{3}{*}{ Y1 } & RH B25A & 31 Aug 93 & \multirow[t]{3}{*}{ Bua (west coast) } & $\mathrm{F}$ & 556 & 297 & $10+$ \\
\hline & RH 56/94 & 29 Aug 94 & & $\mathrm{~F}$ & 405 & 103 & $10+$ \\
\hline & RH 82/94 & 29 Aug 94 & & $\mathrm{~F}$ & 431 & 101 & $13+$ \\
\hline \multirow[t]{3}{*}{ Y2 } & KH 1 & $31 \mathrm{Jul} 95$ & \multirow[t]{3}{*}{ Klagshamn (west coast) } & & 175 & 12.1 & $2+$ \\
\hline & KH 4 & 31 Jul 95 & & & 177 & 10.1 & $2+$ \\
\hline & KH 5 & 31 Jul 95 & & & 176 & 9.9 & $2+$ \\
\hline \multirow[t]{2}{*}{ Y3 } & SK 1 & 26 Aug 95 & \multirow[t]{2}{*}{ Ystad (south coast) } & & 103 & 1.7 & $0+$ \\
\hline & SK 4 & 26 Aug 95 & & & 115 & 2.5 & $0+$ \\
\hline \multirow[t]{2}{*}{ Y4 } & KK 81 & 29 Aug 93 & \multirow[t]{2}{*}{ Kariskrona (south coast) } & $\mathrm{F}$ & 304 & 36 & $5+$ \\
\hline & KK 89 & 29 Aug 93 & & $\mathrm{~F}$ & 325 & 42 & $7+$ \\
\hline \multirow[t]{2}{*}{ Y5 } & JM 3677 & May/Jun 80 & \multirow{2}{*}{ Kvädöfjärden (east coast) } & $\mathrm{F}$ & 560 & 252 & $9+$ \\
\hline & JM 3686 & May/Jun 80 & & $\mathrm{~F}$ & 551 & 235 & $8+$ \\
\hline \multirow[t]{3}{*}{ Y6 } & MS 4035 & Jul/Aug 80 & \multirow[t]{3}{*}{ Motala ström (east coast) } & $\mathrm{F}$ & 292 & 26 & $5+$ \\
\hline & MS 4057 & Jul/Aug 80 & & $\mathrm{~F}$ & 351 & 52 & $7+$ \\
\hline & MS 4058 & Jul/Aug 80 & & $\mathrm{~F}$ & 386 & 78 & $4+$ \\
\hline Y7 & 25693 & 09 Nov 95 & Ången (east coast) & $\mathrm{F}$ & 496 & 137 & $9+$ \\
\hline \multirow[t]{2}{*}{ Y8 } & AB 3576 & May/Jun 80 & \multirow{2}{*}{ Dalälven (east coast) } & $\mathrm{F}$ & 435 & 113 & nd \\
\hline & AB 3644 & May/Jun 80 & & $\mathrm{~F}$ & 364 & 58 & $6+$ \\
\hline \multicolumn{8}{|c|}{ Silver eels } \\
\hline \multirow[t]{2}{*}{ S1 } & RH 4102 & 1993 & \multirow[t]{2}{*}{$\begin{array}{l}\text { Vendelsöfjorden } \\
\text { (west coast) }\end{array}$} & $\mathrm{F}$ & 682 & 578 & $8+$ \\
\hline & RH 4105 & 1993 & & $\mathrm{~F}$ & 818 & 984 & $14+$ \\
\hline \multirow[t]{2}{*}{$\mathrm{S} 2$} & KU 5 & Nov 96 & \multirow[t]{2}{*}{ Kullen (west coast) } & $\mathrm{F}$ & 913 & 1289 & $10+$ \\
\hline & KU 14 & Nov 96 & & $\mathrm{~F}$ & 770 & 847 & $10+$ \\
\hline \multirow[t]{2}{*}{$\mathrm{S} 3$} & JM 3045 & 1992 & \multirow[t]{2}{*}{ Kvädöfjärden (east coast) } & $\mathrm{F}$ & 652 & 558 & $14+$ \\
\hline & JM 3053 & 1992 & & $\mathrm{~F}$ & 872 & 1564 & $20+$ \\
\hline \multirow[t]{2}{*}{ S4 } & SÖ 2058 & Jul 90 & \multirow[t]{2}{*}{ Väddö (east coast) } & $\mathrm{F}$ & 866 & 1372 & $19+$ \\
\hline & SÖ 2081 & Jul 90 & & $\mathrm{~F}$ & 952 & 1790 & $15+$ \\
\hline \multirow[t]{2}{*}{ S5 } & 10116 & 05 Oct 85 & \multirow[t]{2}{*}{ Lake Fardume (Gotland) } & M & 438 & 151 & $5+$ \\
\hline & 17971 & 11 Sep 89 & & $\mathrm{~F}$ & 723 & 651 & $9+$ \\
\hline
\end{tabular}

to that of Groups Y1-5. The ratios averaged $5.8 \pm 1.3 \%$ after the elver stage (Fig. $2 \mathrm{~g}$ ), suggesting that this yellow eel had never been in freshwater.

Temporal changes in $\mathrm{Sr} / \mathrm{Ca}$ ratios of silver eels

Groups S1-4 were collected in brackish water. Their ages ranged between $8+$ and $20+$ years. The two eels in Group S5 were collected from a freshwater lake; their ages were $5+$ and $9+$ years. $\mathrm{The} \mathrm{Sr} / \mathrm{Ca}$ ratio profiles of Groups S1-5, from the primordium to elver stage (Fig. 3), were similar to those of yellow eels; thus, they appear to have shared a similar early life history. The $\mathrm{Sr} /$ Ca ratios of the otolith of Eel No. JM3045 (Group S3) regularly decreased to a low level, indicating that the eel may migrate between brackish water and freshwater during the yellow eel stage. However, this phenomenon was not noted in any other eels of Groups S1-4.

The mean $\mathrm{Sr} / \mathrm{Ca}$ ratios of Groups $\mathrm{S} 1-4$ ranged from 3.7 to $4.6 \%$ or elver to silver eel stages (Fig. 3a to d), whereas the mean $\mathrm{Sr} / \mathrm{Ca}$ ratios of the freshwater eels (Group S5) at corresponding stages were approximately $0.7 \%$ (Fig. 3e). The mean ratios were significantly different between Groups S1-4 and S5 ( $t$-test, $p<0.001$ ). This indicates that the silver eels of Groups S1-4 stayed in brackish water from the elver stage to the silver eel stage.

\section{Discussion and conclusions}

$\mathrm{The} \mathrm{Sr} / \mathrm{Ca}$ ratios in the otoliths of yellow eels in Groups Y1-5 and Y7 and silver eels in Groups S1-4 collected from coastal waters of the Baltic Sea were significantly higher than those of silver eels in Group S5, which were stocked to a freshwater lake as elvers. The Baltic Sea is brackish and has an estuarine character. This indicates that European eels from estuaries may not need to migrate into freshwater during their growth phase. Tsukamoto et al. (1998) also noted that both the European and the Japanese eel matured in offshore waters and did not necessarily migrate to freshwater. On other hand, temporal changes in the $\mathrm{Sr} / \mathrm{Ca}$ ratios of yellow eel otoliths for specimens in Groups Y6 and Y8 indicate that these eels moved from brackish water to freshwater. The ages of the eels in the Baltic Sea ranged from $0+$ to $20+$ years. The above data thus indicate that, during the growth phase, some eels migrate to freshwater while others stay in the sea.

In a study by Tsukamoto et al. (1998) the time series changes of $\mathrm{Sr} / \mathrm{Ca}$ ratios of European eel otoliths prior to metamorphosis showed obvious dissimilarity between ocean samples and freshwater samples. This may indicate that the environmental history of the eels differed before the glass eel stage. However, the time series pattern of the ratios before the glass eel stage was similar 

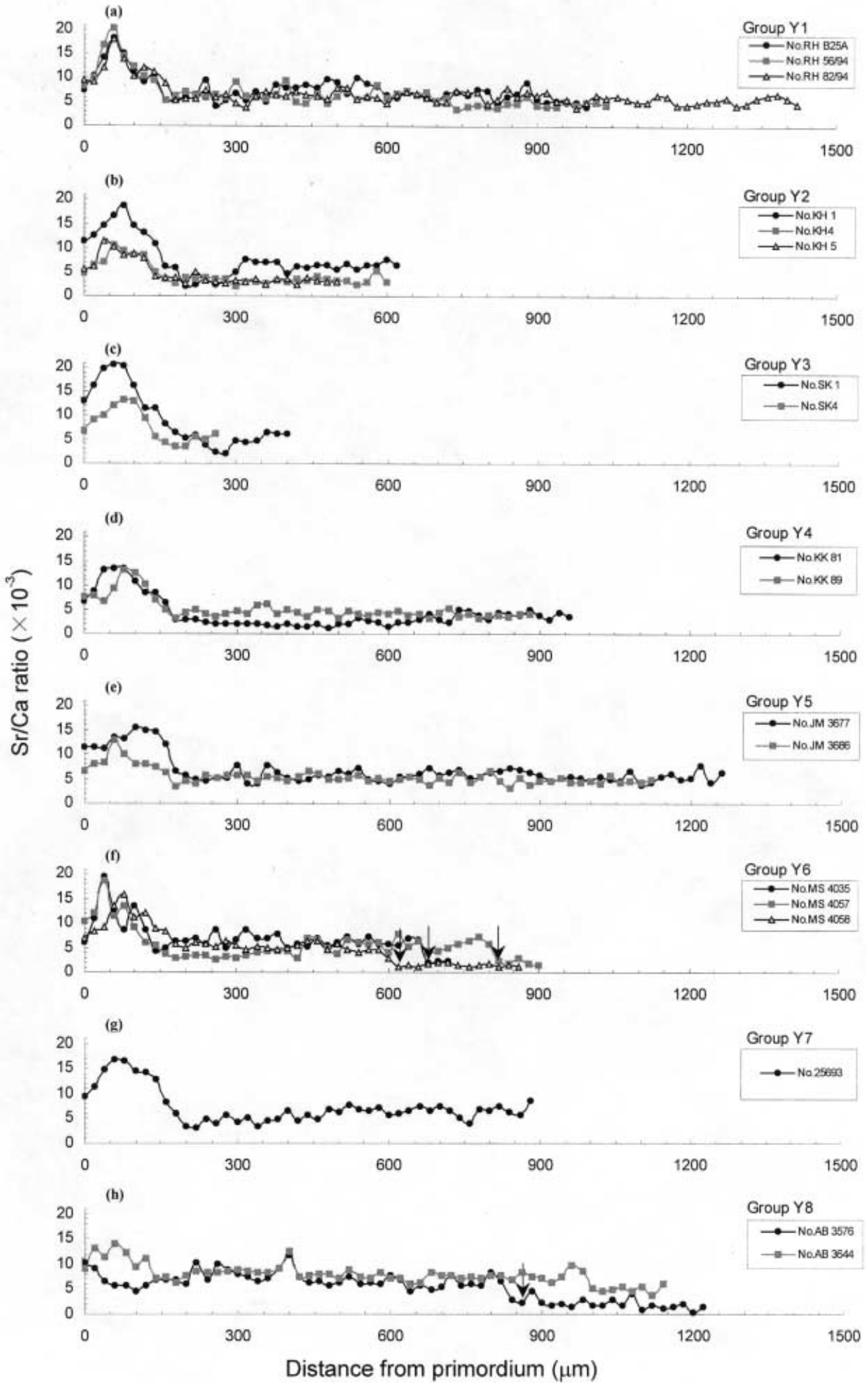

Fig. 2a-h Time series profiles of the $\mathrm{Sr} / \mathrm{Ca}$ ratios of otoliths of yellow eels collected in the coastal waters of Sweden. For specimen numbers in the panel keys see Table 1. Arrows indicate the transition from brackish water to freshwater among marine and freshwater samples in the present study (Figs. 2, 3), as well as in a previous study (Tzeng et al. 1997). Because European eels are believed to have a similar life history in the marine environment prior to the glass eel stage, no matter where yellow and silver eels are 


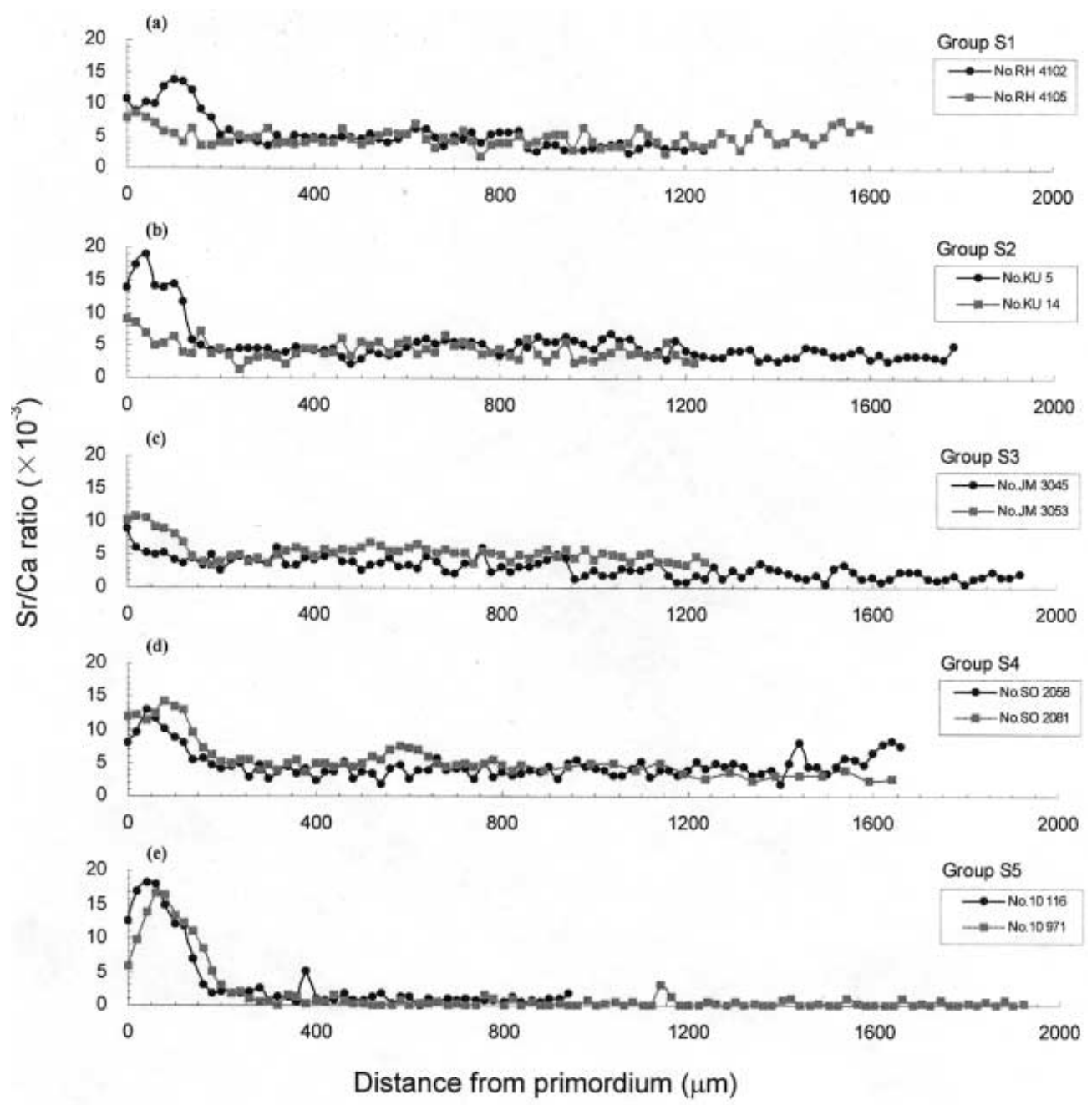

Fig. 3a-e Time series profiles of the $\mathrm{Sr} / \mathrm{Ca}$ ratios of otoliths of silver eels collected in the coastal waters (Groups S1-4) and a freshwater lake (Group S5) of Sweden. For specimen numbers in the panel keys see Table 1

from - ocean or freshwater, North Sea or Baltic Sea their $\mathrm{Sr} / \mathrm{Ca}$ ratios should be the same, unless the leptocephalus of freshwater samples does not metamorphose to the glass eel stage until they have entered freshwater.

It is not clear why during the growth phase some eels migrate to freshwater and others do not. Gross (1987) proposed that diadromy occurs when the gain in fitness from using a second habitat minus the migration costs of moving between habitats exceeds the fitness from staying in only one habitat. The Baltic Sea is a high productive mega-estuary (Westerberg 1996), whereas many inland freshwater bodies in Sweden are oligotrophic (Moriarty and Dekker 1997). In addition, many streams in Sweden have been dammed, and small brooks may periodically dry up in summer. These situations may block the upstream migration of elvers into freshwater and compel them to stay in coastal brackish waters during the growth phase. A similar situation has also been reported for saltwater/brackish lagoons of the Mediterranean Sea and for the lagoons of Arcachon Bay on the Atlantic coast. Because no freshwater flows into these lagoons, eels that enter lagoonal waters at the glass eel stage may stay there until spawning migration (Rossi 1979; Lee 1982). The other possibility is that, due to the low temperatures of inland waters in Sweden, the study area is almost at the northern limit of the species' distribution. The low temperatures influence both the foraging and growth of the eel (Bruun 1963; Sinha and Jones 1967). There are several other known instances in which diadromy is lost at the northern (cold) extremes of a species' distributional range. For example, the white perch Morone saxatilis is anadromous around Chesapeake Bay but not in the colder waters of the Canadian maritime provinces (McDowall 1987). Loss of anadromy has been attributed to the cold temperatures.

In conclusion, the $\mathrm{Sr} / \mathrm{Ca}$ ratios indicate that the European eel might not always have to migrate to freshwater during the fast-growing phase, and may complete its life cycle between marine and brackish waters. Such a life cycle is termed semi-catadromous migration, to distinguish it from the well-known catadromous migration of the eel. 
Acknowledgements This study was financially supported by the National Science Council of the Republic of China (Project No. NSC89-2611-B00-2-004). The authors are grateful to Dr. H. Svedäng for providing otolith specimens, Dr. H. Westerberg of the Swedish Meteorological and Hydrological Institute for supplying oceanographic data, Dr. C.H. Chen of the Department of Geology, National Taiwan University for technical support in conducting the wavelength dispersive electron microprobe analysis, and $\mathrm{Dr} \mathrm{C}$. Mortarty, Dr T.F. Tsai and two anonymous reviewers for helpful comments.

\section{References}

Bertin L (1956) Eels - a biological study. Cleaver-Hume Press, London

Bruun AF (1963) The breeding of the North Atlantic freshwater eel. Adv mar Biol 1: 137-169

Cairns D (1942) Life-history of the two species of New Zealand freshwater eel. I. Taxonomy, age and growth, migration and distribution. NZ J1 Sci Technol (Sect B) 23: 53-72

Casselman JM (1982) Chemical analyses of the optically different zones in eel otoliths. Proc. 1980 N. Amer Eel Conf, pp 74-82

D'Ancona U (1960) The life cycle of the Atlantic eel. Symp zool Soc Lond 1: 61-77

Gross MR (1987) Evolution of diadromy in fishes. In: Dadswell MJ, Klauda RJ, Moffitt CM, Saunfers RL, Rulifson RA, Cooper JE (eds) Common strategies of anadromous and catadromous fishes. Am Fish Soc Symp 1: 14-25

Holmgren K (1996) On the sex differentiation and growth patterns of the European eel, Anguilla anguilla (L.). PhD thesis, Uppsala University, Sweden

Lee TW (1982) Ageing and growth of eel population, Anguilla anguilla, in the lagoons of Arcachon Bay (France). J oceanogr Soc Korea 17: 83-94

McDowall RM (1987) Evolution and importance of diadromy: the occurrence and distribution of diadromy among fishes. In: Dadswell MJ, Klauda RJ, Moffitt CM, Saunfers RL, Rulifson RA, Cooper JE (eds) Common strategies of anadromous and catadromous fishes. Am Fish Soc Symp 1: 1-13

Moriarty C, Dekker W (1997) Management of the European eel. Fish Bull (Dublin) 15: 1-110
Otake T, Ishii T, Nakahara M, Nakamura R (1994) Drastic changes in otolith strontium/calcium ratios in leptocephali and glass eels of Japanese eel Anguilla japonica. Mar Ecol Prog Ser 112: 189-193

Radtke RL, Shafer DJ (1992) Environmental sensitivity of fish otolith microchemistry. Aust J mar Freshwat Res 43: 935951

Rossi R (1979) An estimate of the production of the eel population in the Valli of Comacchio (Po Delta) during 1974-1976. Boll Zool 46: 217-223

Sinha VRP, Jone JW (1966) On the sex and distribution of the freshwater eel (Anguilla anguilla). J Zool, Lond 15: 371-385

Sinha VRP, Jone JW (1967) On the age and growth of the freshwater eel (Anguilla anguilla). J zool Soc Lond 153: 99-117

Tesch FW (1977) The eel: biology and management of anguillid eels. Translated from German by J. Greenwood. Chapman and Hall/John Wiley and Sons, New York

Tsukamoto K, Nakai I, Tesch WV (1998) Do all freshwater eels migrate? Nature 396: 635-636

Tzeng WN (1990) Relationship between growth rate and age at recruitment of Anguilla japonica elvers in a Taiwan estuary as inferred from otolith growth increments. Mar Biol 107: $75-81$

Tzeng WN (1996) Effects of salinity and ontogenetic movements on strontium:calcium ratios in the otoliths of the Japanese eel, Anguilla japonica Temminck and Schlegel. J exp mar Biol Ecol 199: 111-122

Tzeng WN, Tsai YC (1992) Otolith microstructure and daily age of Anguilla japonica Temminck \& Schlegel elvers from the estuaries of Taiwan with reference to unit stock and larval migration. J Fish Biol 40: 845-857

Tzeng WN, Tsai YC (1994) Changes in otolith microchemistry of the Japanese eel, Anguilla japonica, during its migration from the ocean to the rivers of Taiwan. J Fish Biol 45: 671683

Tzeng WN, Severin KP, Wickström H (1997) Use of otolith microchemistry to investigate the environmental history of European eel Anguilla anguilla. Mar Ecol Prog Ser 149: 73-81

Tzeng WN, Wu HF, Wickström H (1994) Scanning electron microscopic analysis of annulus microstructure in otolith of European eel Anguilla anguilla. J Fish Biol 45: 479-492

Westerberg H (1996) Oceanographic aspects of the recruitment of eels to the Baltic Sea. EIFAC/ICES Working Group on Eel, Ijmuiden 